\title{
High pressure applications in low salt gel meat technologies. A review
}

\author{
Yan-Ping $\mathbf{L i}^{1,2}$, Valerii Sukmanov ${ }^{1,3}$, \\ Ma Hanjun'2, Zhuang-Li Kang ${ }^{2}$
}

\author{
1 - Sumy National Agrarian University, Sumy, Ukraine \\ 2 - Henan Institute of Science and Technology, Xinxiang, PR China \\ 3 - Poltava State Agrarian University, Poltava, Ukraine
}

Keywords:

High pressure

Low-salt

Meat

Water holding capacity

Texture

\section{Article history:}

Received 2.09.2021

Received in revised form

01.11.2021

Accepted 30.12.2021

\section{Corresponding author:}

Valerii Sukmanov

E-mail:

sukmanovvaleri@gmail.com

DOI: $10.24263 / 2310-1008-$

2021-9-2-6

\section{Abstract}

Introduction. The aim of this work is to analyze and generalize studies on high-pressure effects for gel meat products with low levels of salt $(1 \%)$, namely, changes in the structure of meat proteins and gel properties.

Materials and methods. Literature analysis.

Results and discussion. A high pressure, as a kind of physical sterilization technology, can effectively change the protein structure and techno-functional features of meat products, while retaining nutritional features and the taste. The effect of water holding capacity, colour, texture and sensory features in low-salt gel meat products under high pressure was reviewed. The effect of processing process parameters (pressure, time and temperature) on low salt gel meat products was analyzed to alter their structure, conformation and gel properties. Meat protein is sensitive to high pressure. The structures of the $\alpha$-helix and $\beta$-sheet changed to those of the random helices and $\beta$ turns as the pressure was increasing. The solubility of the protein and the hardness of the gel reach their maximum indicators, and the microstructure of the gel is optimal dense and uniform at $200 \mathrm{MPa}$. Overall, high pressure processing can be used to produce low-salt gel meat products with good quality. Processing of a beef sausage with a low salt content at a high pressure of $200 \mathrm{MPa}$ leads to increased solubility of myofibrillar proteins such as myosin and actin in salts. The combination of high pressure and heat processing at low salt meat protein denaturation temperatures results in better retention of water and texture than in samples prepared only by heating process. Thus, high pressure processing before heat one improves the functionality of the meat mince.

Conclusions. High-pressure processing can be effectively used in the production of gel meat products with low salt content and high consumer features. 


\section{Introduction}

Sodium chloride is the main source of human sodium intake, and now the low-salt food has been payed more and more attention in recent years (Pretorius et al., 2018; Pateiro et al., 2021). The world health organization (WHO) recommended that the intake of sodium chloride should be 4-6 g/d, but the average intake of sodium chloride in the most countries was much than that (World Health Organisation, 2007; Zhang et al., 2017; Zhang et al., 2017). Excessive intake of sodium chloride can cause hypertension and cardiovascular diseases, increase the average incidence of kidney diseases and gastric cancer (Bistola et al., 2020; Tobin et al., 2013; Datta et al., 2007). The historical experience of salt reduction shows that reducing the per capita sodium chloride intake requires the effective participation of food processing industry (Aliño et al., 2010; Paula et al., 2019; Li et al., 2021), among which the most effective method is adopt new processing technology to reduce the sodium chloride content in meat products. According to the traditional thermal gel mechanism of meat proteins, sufficient sodium chloride can extract the salt-soluble protein, such as myosin and actin, to form good texture and taste. The way of directly reduced sodium chloride could cause the product yield and edible quality were significantly reduced (Barbut et al., 1988; Desmond et al., 2006; Li et al., 2021). Therefore, how to reduce sodium chloride content while ensuring the good quality of product has become an urgent problem to be solved in the meat industry.

The use of high pressure technology to reduce sodium chloride content in the gel type meat has been reported by some researchers (Barbut et al., 1988; Desmond et al., 2006; Li et al., 2021; Li et al., 2020; Li et al., 2021; Lu et al., 2021; Dixon et al., 2019; Dixon et al., 2019). Due to the structural of protein material component differences appear different degree of compression deformation, when the deformation degree is large enough, it may affect the combination between protein molecules formed, and cause the destruction and restructuring, which affects the functional characteristics of protein. Moreover, protein molecule conformation may bring better functional characteristics due to sudden release of pressure after pressure is withdrawn (Gao et al., 2018; Xu et al., 2019; Wei et al., 2019). The high pressure processing plays a key role in forming the quality of the meat products, there are a few reports on reducing salt content in the meat products, but the mechanism of lowering sodium chloride was still not completely understand (Jayathilakan et al., 2019).

One of prospective directions of improving meat products technologies in the direction of reducing their salt content is a high pressure technology. Its usage does not reduce the amount of introduced sodium chloride from 1.8 to $1.2 \%$ in the recipe composition of pork sausage, but also improves its technological and consumerist features (Li et al., 2021). Some general principles and laws that allow developing a goal-oriented strategy for managing meat products technologies describe these changes.

\section{Effects of sodium chloride in gel meat products}

Sodium chloride plays an important role in gel meat products. First, sodium ions and chloride ions can stimulate taste. Second, myofibrillar protein can be extracted to facilitate the dissolution and swelling, it increases the water- and oil-retaining properties of the gel, and improves product yield, texture and shelf life (Li et al., 2020, Li et al., 2020; Kang et al., 2014; Alvarez et al., 2007; Yao et al., 2017; Inguglia et al., 2017; Kang et al., 2018). The function of dissolving and extracting myofibrillar is called the processing effect of sodium chloride, which is the key to form the quality of gel meat products (Lu et al., 2021; Zhu et 
al., 2018; Mancini et al., 2019). The swelling of myofibrillar is also very important for the processing of meat products, it is wrapped around the meat and fat particles or liquid drops. During heating, the substances are cross-linked and the water is trapped in the protein matrix. Sodium ions can form electron clouds around myofibrillar molecules and promote the dissolution of myofibrillar protein (Offer et al., 1983). In fact, the sodium chloride content from 1 to $1.5 \%$ can meet the majority of consumers' demand for salty taste, however, to meet the processing required, the gel meat products generally add 2 to $4 \%$ sodium chloride (Hand et al., 1982).

The biggest obstacle to reduce sodium chloride in meat products is that sodium chloride is a very cheap ingredient, and consumers are more comfortable with the quality and flavor of meat products with adding salt. On the premise that consumers can accept, the main ways to reduce the sodium content of gel meat products are summarized as follows: reduced the amount of sodium chloride added and replaced with other salt; the Glutamine transaminase is added to catalyze the interprotein (or internal) acyl transfer reaction to form covalent crosslinking between proteins (or polypeptides) (Colmenero et al., 2005; Kang et al., 2016). The new process can improve the performance of myofibrillar, and still form a good thermally induced gel at low ionic strength (Desmond et al., 2006; Inguglia et al., 2017; Kang et al., 2016).

The overall use of salt substitutes is difficult for consumers to accept, but the partial reduction of salt in meat products is a desirable approach. There are many kinds of salt, but few of them can be used to process gel meat products successfully or completely instead of salt (Inguglia et al., 2017; Kang et al., 2017; Mariutti et al., 2017).

In most studies, sodium chloride was replaced by other chloride salts, because the processing effect of sodium chloride is mainly achieved through the binding of chloride ions with proteins. The decrease of chloride ion content is lead to a significant decline in gel properties. At present, the most successful alternative salt in the study is potassium chloride, which can replace about $35 \sim 40 \%$ sodium chloride in the formula of gel meat products, but excessive potassium chloride will produce bitter and other bad smells (Zhang et al., 2017). Polyphosphate can increase the $\mathrm{pH}$ of meat chyme, cause muscle fibrils to swell, facilitate actomyosin dissociation, so it can partially replace sodium chloride. Reducing sodium chloride crystal size and changing crystal shape can reduce the amount of sodium chloride added without affecting food saltiness. However, gel meat products contain a lot of water, and sodium chloride is dissolved in water, so the effect of reducing the content of sodium chloride in gel meat products, thus, this method is limited (Angus et al., 2006).

Another way is to use flavor enhancers. Flavor enhancers increase the saltiness and flavor of low-salt meat products, it decrease the use of salt without reducing the saltiness and flavor of meat products. Some flavor enhancers and shaders have been used in industrial production, and the usage is increasing, such the products include yeast extract, lactate, sodium glutamate and nucleotide. Flavor enhancers can stimulate the taste and reduce the stimulation of sodium chloride to the taste nerve, helping to reduce the amount of sodium chloride used. Pasin et al. (1989) used potassium chloride and nucleotide mixture (50\% IMP and GMP mixture used commercially) to reduce salt in pork sausages by $75 \%$; Any amount of glutamate in these pork sausages combined with potassium chloride can be substituted for $50 \%$ salt (Pasin et al., 1989). Ruusunen (Ruusunen et al., 2001) found that adding glutamate sodium or nucleotide mixture to bonian-type sausages could enhance their flavor, there was not significant changed after 17 days stored, and the sausage with adding glutamate sodium or nucleotide mixture had a better overall acceptability, while the sausage with adding flavour enhancer had a good edible quality (Ruusunen et al., 2001). Other compound flavor enhancers, such as lysine and succinic acid mixtures, have been studied as substitutes for salt. 
This kind of complex has the flavor of salt, as well as antibacterial and antioxidant properties. It can replace $75 \%$ of salt and has a good development prospect (Triki et al., 2017). Through adding phosphate, starch and hydrocolloid can make up for the effect of decreased water retention and product quality of low-salt meat products. The use of different levels of potassium lactate or sodium lactate as an alternative salt to maintain the product's flavor and saltiness (Omana et al., 2011).

Due to the differences in muscle physiology and structure, especially the composition of free amino acids that can react with glutamine transaminase, such as the number and distribution of amino acid residues, the effects of different types of muscle proteins are different, but the heavy chain of myosin is sensitive to glutamine transaminase. Transglutaminase greatly changes the structure of myosin heavy chain, leads to the ligninhelical structure is reduced, and the lignin-folding structure is increased, resulting in the generation of polymers, improving the texture of the gel and forming a orderly gel structure (Luisa et al., 2015). The other, added glutamine transaminase into $1 \%$ sodium chloride content of chicken meatballs can improve the yield and gel strength, forming a dense and ordered gel structure (Fellendorf et al., 2016). Edrosolam et al. found that added glutamine transaminase into low-salt and low-fat bonija sausage, who found that the addition amount of $0.15 \%$ could increase the elasticity, hardness and cohesion of the hot gel (Edrosolam et al., 2014).

\section{The principle of high pressure processing}

High pressure processing (HPP), can be referred to as ultra high pressure technology or hydrostatic technology, the water or other incompressible fluid mediums often act as mediators of pressure. During the high pressure processing, the pressure levels generally not less than $100 \mathrm{MPa}$, the commonly used range is $100-1000 \mathrm{MPa}$ and can work in the temperature range of -20 to $90{ }^{\circ} \mathrm{C}$. After the food is sealed in an elastic container or placed in a pressure system, the non-covalent bonds (hydrogen bonds, ionic bonds and hydrophobic bonds, etc.) are been destroyed or formed at a certain temperature for the appropriate processing time and pressure level, which cited the enzyme in food, protein, starch and other biological high molecular substances are deactivated, denatured and gelatinized respectively, and kill the microorganism in food biological, so as to achieve the purpose of food sterilization, preservation and processing (Wael et al., 2015).

As with heat, pressure is a basic thermodynamic variable. Strictly speaking, during HPP the effects of temperature cannot be separated from the effects of pressure. This is because for every temperature there is a corresponding pressure. Thermal effects during pressure treatment can cause volume and energy changes. However, pressure primarily affects the volume of the product being processed. The combined net effect duringHPPmay be synergistic, antagonistic, or additive (Koutchma T. et al., 2012).

Mathematically, the impact of pressure $(p)$ and temperature $(T)$ can be quantitatively related using Gibbs's definition of free energy $G$ (Koutchma T. et al., 2012):

$$
G \equiv H-T S,
$$

where $H$ and $S$ are the enthalpy and entropy, respectively. Further,

$$
H \equiv U+p V,
$$

where $U=$ internal energy and $V=$ volume. 
It can be deduced from Equations 1 and 2 that

$$
d(\Delta G)=\Delta V d p-\Delta S d T
$$

Therefore, reactions such as phase transitions or molecular reorientation depend on both temperature and pressure and cannot be treated separately. Thefollowing are some basic governing principles behind HPP.

The fundamental principles of hyperbaric technique are Pascal's law and Le Chatelier principle. Pascal's law takes advantage of the compression effect of high pressure on liquids, which means that the pressure applied to the liquid can be transmitted to all parts of the system instantaneously at the same size. Therefore, dry food, powdery food or granular food should not be used high pressure treatment. According to Pascaline law, the effect of high pressure processing is independent of the size, shape and volume of the food. In the process of high pressure processing, the whole food will be treated uniformly, the pressure transfer speed is fast, there is no pressure gradient.Therefore, the high pressure processing of food is simpler, and the energy consumption is also significantly reduced. According to Le Chatelier principle, the external pressure reduces the volume of the pressurized system and vice versa. Therefore, the physical and chemical reactions in food ingredients will be carried out in the direction of the maximum compression state under the pressure treatment of food. The increase or decrease of the reaction rate constant $k$ depends on whether the "active volume" of the reaction is positive or negative. This means that high pressure processed food will force the reaction system to reduce the volume, affecting not only the reaction balance in the food, but also the reaction rate, including chemical reactions and possible changes in molecular conformation. It is well known that the mechanism of meat proteins unfolded, denaturation and formed gel caused by heat and high pressure is difference. High pressure processing induced meat gels are based on the protein volume decline, while the thermal meat gels is caused by the violent movement of molecules and destruction of non-covalent bonds.

At constant temperature, an increase in pressure increases the degree of ordering of molecules of a given substance. Therefore, pressure and temperature exert antagonistic forces on molecular structure and chemical reactions.

As with thermal processing, various reaction rates during HPP are also influenced by thermal effects during pressure treatment. The net pressure-thermal effects can be synergistic, additive, or antagonistic.

High-pressure processing of muscle based products is paying more and more attention in the meat industry, which could prolong the shelf life of meat products, inactivate vegetative micro-organisms and enzymes near room temperature, because of the processing allows the decontamination of muscle based products with minimal impact on their nutritional and sensory features. Therefore, The application of high pressure offers some interesting opportunities in the processing of muscle-based food products, such as, the high pressure can affect the texture and gel-forming properties of meat batter and myofibrillar proteins, the tenderize, color and other properties of muscle. The processing effects on muscle based products are highly dependent on the primary effects of pressure, time and temperature on the relevant thermodynamic and transport properties of meat systems. However, the pressurelabile nature of some meat protein systems, such as myosin or myoglobin often limits the range of attractive commercial applications to prefermented and cooked meat products. 


\section{Use of high pressure in meat products}

Improving processing techniques and equipment can also reduce sodium chloride of meat products. The application of high pressure technology in food has a long history. As early as 1895 , Royer found that high pressure treatment can kill bacteria. In 1899, Hite first discovered that $450 \mathrm{MPa}$ pressure could extend the storage period of cow milk. Brigman, an American physicist with the reputation of "pioneering the study of modern high pressure technology", who has been conducting systematic research on the high pressure effects of macroscopic behaviors such as solid compressibility, mechanical properties. In 1914, the high pressure technology of food was defined, and report that the albumin solidified under $500 \mathrm{MPa}$ and became hard gel under $700 \mathrm{MPa}$ was proposed (Bridgman et al., 1914). High pressure treatment led to change in the structure of protein molecules by affecting the molecular volume and non-covalent bond of protein, thus improving their functional activity (Ngarize et al., 2004; Xu et al., 2016).

\subsection{Effect of high pressure on tenderness in meat products}

High pressure treatment has a certain tenderizing effect on meat. The tenderness of meat after high pressure treatment is increased, indicates that the muscle node structure is damaged and the muscle fiber structure is changed during pressure treatment (Tauc. et al., 2002; Perrett et al., 2002; . Ma et al., 2013; Warner et al., 2019). The tenderizing mechanism of high pressure on meat mainly has two aspects:

1. Mechanical force causes the binding dissociation of muscle actin and myosin in muscle fibers, muscle fiber disintegrates and muscle fibrin dissociates into small fragments, resulting in a decrease in muscle shear force;

2. Pressure treatment causes the activation of endogenous proteinase-calcium enzymes in muscles (Cioni et al., 2002; Simonin et al., 2012).

Accompanied by the tenderizing, the changes of meat color was generated treated by high pressure. The myoglobin and hemoglobin in the myoplasm gradually denature under pressure and lose their inherent red color, resulting in the red color of muscles gradually becoming lighter and gray, and finally turning gray like cooking meat (Orlien et al., 2014; Wang et al., 2020). When the pressure is lower than $200 \mathrm{MPa}$, the appearance of meat does not change much, but the color of meat fades when the pressure is higher than $200 \mathrm{MPa}$. The reasons of pressure processing of meat color are as follows:

1. The pressure between $200 \sim 350 \mathrm{MPa}$, the white color ( $\mathrm{L}^{*}$ value) was probably globulin of myoglobin degeneration or heme is replaced or lose.

2. The pressure loss of red when more than $400 \mathrm{MPa}$, due to ferrous myoglobin oxidation into high-speed rail by myoglobin (Canto et al., 2012; Ha, 2017). The occurrence of the above two changes are main dependent on whether exceeds the pressure required for the change, and less affected by the pressure and time.

\subsection{Effect of high pressure on oxidation in meat products}

Some studies have investigated that the influence of high pressure on fat stability of meat products is related to oxygen, composition of meat and temperature. The effect of high pressure on lipids is reversible, and lipids are stable under appropriate high pressure. In the presence of meat tissue, the pressure at room temperature over $300 \mathrm{MPa}$ is aggravated the rate of lipid oxidation, and the TBA value of peroxides is higher than that of unpressurized lipids (Tuboly et al., 2003; Chen et al., 2018; Bernasconi et al., 2020; Rivas-Caedo et al., 
2021; Martínez-Onandi et al., 2019). Under the condition of high temperature, the inhibition effect of high pressure treatment on fat oxidation will disappear. High pressure induced fat oxidation limits the application in meat processing. Metal chelating mixture can effectively eliminate the initiation of fat oxidation and become an ideal antioxidant to prevent fat oxidation in meat treated by high pressure (Guyona et al., 2016; Cava et al., 2020).

\subsection{Effect of high pressure on bacteria in meat products}

High pressure can destroy the cell wall and cell membrane of bacteria, inhibit the activity of enzymes and the replication of genetic materials such as DNA, destroy the hydrogen bond, disulphide bond and ionic bond of proteins, and finally cause the death of microorganisms (Delgado et al., 2015; Park et al., 2006; Garriga et al., 2002). As the temperature increases (decreases) with the pressure (pressure relief) during the high pressure treatment, the temperature increases $2 \sim 4{ }^{\circ} \mathrm{C}$ for every $100 \mathrm{MPa}$ of pressure increase. Thus, in recent years, it has also been considered that the lethal effect on microorganisms is the result of the combined action of compression heat and high pressure (Cava et al., 2020; Yuste et al., 1999; Ko et al., 2002; Wang et al., 2021). It is well known that gram-negative bacteria and yeast can be basically killed at a pressure of about $400 \mathrm{MPa}$, while gram-positive bacteria need to be killed at a pressure of $600 \mathrm{MPa}$, while to kill spore bacteria requires a higher pressure and proper heating and prolongs holding time. The killing effect of spore bacteria can be improved obviously if the high pressure pulse treatment is applied alternately to pressure and pressure relief (Bonilauri et al., 2021; Jung et al., 2003; Macfarlane et al., 1985).

\section{The use of high pressure in low-salt meat products}

The high pressure treatment improves the functional properties of meat protein, and is beneficial for reducing salt (Chen et al., 2018; Duranton. et al., 2012; Zheng et al., 2017). Such as, the surface hydrophobicity and total sulfhydryl groups of rabbit myosin were increased under high pressure between 100 and $200 \mathrm{MPa}$ (Chapleau et al., 2004). Meat protein is sensitive to the high pressure treatment. The $\alpha$-helix and $\beta$-sheet structures changed into random coil and $\beta$-turn structures as the pressure levels increased; moreover, the protein solubility and gel hardness reached their maximum values and the gel microstructure was dense and uniform at $200 \mathrm{MPa}$. Thus, a better understanding of the changes in gel properties and protein conformations occurring in meat products induced by combined high pressure and thermal conditions could be helpful to elucidate their role during gel formation and facilitate the development of new healthy meat products (Zheng et al., 2017; Zhang et al., 2017; Yang $\mathrm{H}$ et al., 2021).

Sensory evaluation was conducted after the high pressure treatment of low-salt frankfurter by high pressure, and it was found that the tasters were more likely to accept the sausages treated with low salt and high pressure, which indicated that high pressure could improve the texture of the sausages, and partially reduce the amount of salt (Crehan et al., 2000). Grossi et al. (Grossi et al., 2011) reported that the use of high pressure technology could reduce the sodium chloride content from $1.8 \%$ to $1.2 \%$ of pork sausage with carrot fiber and potato starch, and had no negative impact on the water-retaining performance, color and texture. The other, increased the pressure and temperature, and the meat batter with carrot fiber forms a highly elastic, organically combined and orderly network structure (Grossi et al., 2011; Sun J., et al., 2012). 


\subsection{Effect of high pressure on cooking yield in low-salt meat products}

The water and fat holding capacity is an important indicator the quality of meat products, it expresses the ability of comminuted meat products to hold water and fat. The pressure intensity, salt content, meat type, composition, temperature and others factors independently affected both the water and fat holding capacity of comminuted meat products (Sukmanov et al., 2019a; Sukmanov et al., 2019b). Zheng et al. (Zheng et al., 2017) reported that the cooking loss of low-salt chicken meat batters treat by high pressure was not decreased, this suggested that high pressure was much more effective, than salt in reducing water loss during the cooking. Because of the 100 or $200 \mathrm{MPa}$ is too low to affect the exposure of buried sulfhydryl groups, the SH content of myosin was not significantly differences; at $300 \mathrm{MPa}$ and above, the $\mathrm{SH}$ content was significantly increased, the increase of sulfhydryl groups might be explained by the change of myosin structure. Rospolski et al. (Rospolski et al., 2015) studied the effects of high pressure parameters and $\mathrm{NaCl}$ concentration on the physical properties chicken meat batter, showed that the water became slightly more tightly bound to the meat matrix after high pressure processing treatment, the reason is that high pressure processing could increase the solubility of meat protein, so that, increased water and fat holding capacity and decreased mechanical water loss (Hugas et al., 2002; Chan J et al., 2011).

\subsection{Effect of high pressure on texture in low-salt meat products}

The texture is an important characteristic of meat products, which decides the edible quality of low-salt meat product. It is well known that high pressure processing is an important thermodynamic parameter that can profoundly influence molecular systems. Due to the myofibrillar protein became unfolded with the pressure increased, more buried hydrophobic residues were exposure and more hydrophobic sites or pockets of protein molecules, then the large protein aggregates was formed. When the pressures over $400 \mathrm{MPa}$ can readily denature proteins, and $200 \mathrm{MPa}$ only affects their quaternary structures, leading to the dissociation of oligomeric proteins (Aertsen 2009; Bai et al., 2021). Ngarize et al. (2004), Grossi et al., (2016) found that the solubility of myofibrillar proteins was decreased when the pressure up to $400 \mathrm{MPa}$ and above, due to the protein-protein interaction at 400 $\mathrm{MPa}$ is formed at the expense of protein-water interactions, and the intermolecular $\mathrm{H}$-bonds between proteins are stronger than the H-bonds between protein and water. Yang et al. (Yang et al., 2015) have investigated that the use of high pressure processing for enhancing the functional properties of reduced-fat $(20 \%)$ and reduced-salt (1\%) pork sausages without the need for additives, who found that the textural properties of hardness, chewiness, springiness, cohesiveness and resilience were significantly $(\mathrm{P}<0.05)$ increased at an interval of $100 \mathrm{MPa}$ and $200 \mathrm{MPa}$, except the adhesiveness up to $200 \mathrm{MPa}$, but no changes of of hardness, chewiness, springiness and resilience were observed up to $300 \mathrm{MPa}$ and $400 \mathrm{MPa}$. Because the myofibrillar proteins, such as myosin and actin, were more salt soluble when low-salt beef sausage batters were subjected to high pressure at $200 \mathrm{MPa}$ than the untreated batter (Sikes et al., 2009; Tintchev et al., 2013). (Oflynn et al., 2014) found that high pressure treatment is a potential technology to manufacture sausages maintaining sensory and functional properties, and could decrease the salt levels in reduced-phosphate breakfast sausages, improve the juiciness and cohesiveness. 


\subsection{Effect of high pressure and heat combination in low-salt meat products}

It is well known that the mechanism of meat protein denaturation and formed gel caused by heat and high pressure are differences. The high pressure treatment induced meat gels is based on the protein volume decline, while the thermal meat gels is caused by the violent movement of molecules and destruction of non-covalent bonds. Some researches have reported the effected of low-salt meat products on the combination of heat and high pressure (Chen et al., 2018; Zheng et al., 2017; Tintchev et al., 2013; Oflynn et al., 2014; Khan. et al., 2014; Zheng H. et al., 2019). The temperature during high pressure processing also affected water and fat holding capacity, and gel properties. Combining high pressure and heat treatment at low-salt meat protein denaturation temperatures in a single-step process has reportedly resulted in better water retention and texture than heat-only samples (JimenezColmenero et al., 1998; Zheng et al., 2017; Zheng. et al., 2015). High pressure treatment prior to thermal processing improves the functionality of meat batters. Wei et al. (Wei et al., 2019) studied the effects of protein conformations and gel characteristics of low-salt ( $1 \%$ sodium chloride) pork batters produced by high pressure prior to heating $\left(20-60{ }^{\circ} \mathrm{C}\right)$, who found that the highest cooking yield, hardness, springiness, chewiness, and $\mathrm{G}^{\prime}$ values were observed in batters made by high pressure at 20 and $30{ }^{\circ} \mathrm{C}$. Meanwhile, the $\alpha$-helix structure was significantly decreased, and accompanied by the increase of $\beta$-sheet, $\beta$-turn, and random coil structures at $20-40{ }^{\circ} \mathrm{C}$. The reason is possible that the maximal solubilization of myofibrillar protein occurred at $200 \mathrm{MPa}$, with a reduction of salt content by $50 \%$ and improvement of functional properties, such as water-holding capacity and texture (Tintchev et al., 2013). Zheng et al. (Zheng H. et al., 2019) investigated the effect of appearance, texture, water holding capacity, sensory attributes and microstructure of chicken breast meat batters by heating under $0-400 \mathrm{MPa}\left(75^{\circ} \mathrm{C}, 30 \mathrm{~min}\right)$, the result was that the high pressure, rather than salt, was the main factor affecting the quality of chicken meat batter, the quality of low-salt chicken batter was improved by heating under $200 \mathrm{MPa}$ and formed a fibrous network inside muscle fibers; meanwhile, application of HUP at a specified pressure was an excellent process for producing low-salt comminuted meat products; but excessive high-pressure resulted in inferior quality.

\section{Conclusion}

High pressure has been widely applied and developed rapidly in practical production due to its leading technical characteristics, good economic and social benefits. The effects of high pressure on various components of low-salt meat products vary greatly with the pressure, temperature and time. In spite of great efforts, the mechanism of high pressure on low-salt meat products has not yet been obtained, which leads to get a clear understanding of their behaviour is difficult. Even so, with the development of research, people will have a better understanding on the influence of high pressure in low-salt meat products and its relationship with the change of meat quality. Thus, the use of high pressure processing could improve the quality of low-salt meat products.

Acknowledgments. This study was supported by Natural Science Foundation of Henan Province (no. 212300410344), Research Project of Sichuan Cuisine Development Research Center of Sichuan Education Department (no. CC20Z19) and Henan province key young teachers training program (no. 2018GGJS114). 


\section{Reference}

Aertsen A., Meersman F., Hendrickx M. E. G., Vogel R. F., Michiels C. W. (2009), Biotechnology under high pressure: applications and implications, Trends in Biotechnology, 27(7), pp. 434-441, DOI: 10.1016/j.tibtech.2009.04.001.

Aliño M., Grau R., Fuentes A., Barat J. M. (2010), Characterization of pile salting with sodium replaced mixtures of salts in dry-cured loin manufacture, Journal of Food Engineering, 97, pp. 434-439, DOI: 10.1016/j.jfoodeng.2009.10.039.

Alvarez D., Castillo M., Payne F.A., Garrido M.D., Banón S., Xiong Y.L. (2007), Prediction of meat emulsion stability using reflection photometry, Journal of Food Engineering, 82, pp. 310-315, DOI: 10.1016/j.jfoodeng.2007.02.031.

Angus F., PhelpsT., Clegg S., Narain C., Den Ridder C., and Kilcast D. (2006), Salt in Processed Foods: Collaborative Research Project, Leatherhead Food International, DOI: 10.1016/j.meatsci.2006.04.014.

Bai Y., Zeng X., Zhang C., Zhang T., Xu X. (2021), Effects of high hydrostatic pressure treatment on the emulsifying behavior of myosin and its underlying mechanism, LWT - Food Science and Technology, 111397, DOI: 10.1016/j.lwt.2021.111397.

Barbut S. Mittal G. S. (1988), Rheological and gelation properties of meat batters prepared with three chloride salts, Journal of Food Science, 53, pp. 1296-1299, DOI: 10.1111/j.1365-2621.1988.tb09261.x.

Bernasconi A., Szerman N., Vaudagna S. R., Speroni F. (2020), High hydrostatic pressure and soybean protein addition to beef patties: Effects on the formation of mixed aggregates and technological parameters, Innovative Food Science Emerging Technologies, 66, 102503, DOI: 10.1016/j.ifset.2020.102503.

Bistola V., Arfaras-Melainis A., Trogkanis E., Bakosis G., Polyzogopoulou E., Karavidas I., Ikonomidis I., Parissis J., Karavidas A. (2020), Safety and efficacy of salt substitution with a low sodium-potassium enriched dietary salt in patients with heart failure with reduced ejection fraction: A pilot study, Clinical Nutrition ESPEN, 35, pp. 90-94, DOI: 10.1016/j.clnesp.2019.11.004.

Bonilauri P., Ramini M., Bardasi L., Tomasello F., Serraino A. (2021), Update on a model to describe salmonella spp. population reduction in Italian salami during production and high-pressure processing, Meat Science, 177(5), 108506, DOI: 10.1016/j.meatsci.2021.108528.

Bridgman P. W. (1914), The coagulation of albumen by pressure. Biology Chemistry, (19), pp. 511-512.

Byreddy Naveena, Nagaraju M (2020), Review on principles, effects, advantages and disadvantages of high pressure processing of food, International Journal of Chemical Studies, 8(2), pp. 2964-2967, DOI: 10.22271/chemi.2020.v8.i2at.9202.

Canto A. C. V. C. S., Lima B. R. C. C., Cruz A. G. Lazaro C. A., Freitas D. G. C., Faria J. A. F., et al. (2012), Effect of high hydrostatic pressure on the color and texture parameters of refrigerated caiman (caiman crocodilus yacare) tail meat, Meat Science, 91(3), pp. 255-260, DOI: 10.1016/j.meatsci.2012.01.023.

Cava R., García-Parra J., Ladero L. (2020), Effect of high hydrostatic pressure processing and storage temperature on food safety, microbial counts, color and oxidative changes of a traditional dry-cured sausage, LWT-Food Science and Technology, 128, 109462, DOI: 10.1016/j.lwt.2020.109462.

Chai H., Sheen S. (2021), Effect of high pressure processing, allyl isothiocyanate, and acetic acid stresses on Salmonella survivals, storage, and appearance color in raw 
ground chicken meat, Food Control, 123, 107784, DOI: 10.1016/j.foodcont.2020.107784.

Chan J. T. Y., Omana D. A., Betti M. (2011), Effect of ultimate $\mathrm{pH}$ and freezing on the biochemical properties of proteins in turkey breast meat, Food Chemistry, 127, pp. 109-117, DOI: 10.1016/j.foodchem.2010.12.095.

Chapleau N., Mangavel C., Compoint J. P., De Lamballerie-Anton M. (2004), Effect of high-pressure processing on myofibrillar protein structure, Journal of the Science of Food and Agriculture, 84, pp. 66-74. DOI: 10.1002/jsfa.1613.

Chen X., Tume R. K., Xiong Y. L., Xu X., Zhou G., Chen C., Nishiumi T. (2018), Structural modification of myofibrillar proteins by high-pressure processing for functionally improved, value-added, and healthy muscle gelled foods. Critical Reviews in Food Science and Nutrition, 58(17), pp. 2981-3003, DOI: 10.1080/10408398.2017.1347557.

Cioni P., Strambini G. B. (2002), Tryptophan phosphorescence and pressure effects on protein structure, Biochimica et Biophysica Acta, 1595(1-2), pp. 116-130, DOI: 10.1016/S0167-4838(01)00339-9.

Colmenero F. J., Ayo M. J., Carballo J. (2005), Physicochemical properties of low sodium frankfurter with added walnut: effect of transglutaminase combined with caseinate, $\mathrm{kcl}$ and dietary fibre as salt replacers, Meat science, 69(4), pp. 781-788, DOI: 10.1016/j.meatsci.2004.11.011.

Crehan C. M., Troy D. J., Buckley D. J. (2000), Effects of salt level and high hydrostatic pressure processing on frankfurters formulated with 1.5 and $2.5 \%$ salt, Meat Science, 55, pp. 123-130, DOI: 10.1016/S0309-1740(99)00134-5.

Datta A. K., Sablani S. S. (2007), Mathematical modelling techniques in food and bioprocesses: an overview, Food and Bioprocesses Modeling Techniques, CRC Press, Canada, pp. 1-11, DOI: 10.1201/9781420015072.

Delgado F. J., Rodríguez-Pinilla J., Márquez G., Roa I., Ramírez R. (2015), Physicochemical, proteolysis and texture changes during the storage of a mature soft cheese treated by high-pressure hydrostatic, European Food Research and Technology, 240(6), pp. 1167-1176, DOI: 10.1007/s00217-015-2420-3.

Desmond E. (2006), Reducing salt: A challenge for the meat industry, Meat Science, 74, pp. 188-196, DOI: 10.1016/j.meatsci.2006.04.014

Dixon E., Rabanser I., Dzieciol M., Zwirzitz B., Wetzels S. U. (2019), Reduction potential of steam vacuum and high-pressure water treatment on microbes during beef meat processing, Food Control, 106, 106728, DOI: 10.1016/j.foodcont.2019.106728.

Duranton F., Guillou S., Simonin H., Chéret R., De Lamballerie M. (2012), Combined use of high pressure and salt or sodium nitrite to control the growth of endogenous microflora in raw pork meat, Innovative Food Science Emerging Technologies, 16, pp. 373-380, DOI: 10.1016/j.ifset.2012.08.004.

Edrosolam M. G., Shand P. J. (2014), Utilization of flaxseed meal and microbial transglutaminase in processing of low-salt, low-fat bologna, Meat Science, 96, pp. 120-121, DOI: 10.1016/j. meatsci.2013.05.049.

Fellendorf S., O'Sullivan M. G., Kerry J. P. (2016), Impact of ingredient replacers on the physicochemical properties and sensory quality of reduced salt and fat black puddings, Meat Science, 113, pp. 17-25, DOI: 10.1016/j.meatsci.2015.11.006.

Gao R., Wang Y., Mu J., Shi T., Yuan L. (2018),Effect of L-histidine on the heat-induced aggregation of bighead carp (Aristichthys nobilis) myosinin low/high ionic strength solution, Food Hydrocolloids, 75, pp. 174-181, DOI: 10.1016/j.foodchem.2019.05.095. 
Garriga M., Aymerich M. T., Costa S., Monfort J. M., Hugas M. (2002), Bactericidal synergism through bacteriocins and high pressure in a meat model system during storage, Food Microbiology, 19(5), pp. 509-518, DOI: 10.1006/fmic.2002.0498.

Grossi A., Olsen K., Bolumar T., Rinnan Å., Ogendal L. H., Orlien V. (2016), The effect of high pressure on the functional properties of pork myofibrillar proteins, Food Chemistry, 196, pp. 1005-1015, DOI: 10.1016/j.foodchem.2015.10.062.

Grossi A., Soltoft-Jensen J., Knudsen J. C., Christensen M., Orlien V. (2011), Synergistic cooperation of high pressure and carrot dietary fibre on texture and colour of pork sausages, Meat Science, 89, pp. 195-201, DOI: 10.1016/j.meatsci.2011.04.017.

Guyona C., Meynierb A., Lamballerie M. (2016), Protein and lipid oxidation in meat: a review with emphasis on high-pressure treatments, Trends in Food Science Technology, 50, pp. 131-143, DOI: 10.1016/j.tifs.2016.01.026.

Ha M., Dunshea F. R., Warner R. D. (2017), A meta-analysis of the effects of shockwave and high pressure processing on color and cook loss of fresh meat, Meat Science, 132, pp. 107-111, DOI: 10.1016/j.meatsci.2017.04.016.

Hand L. W., Terrell R. N., Zhou G H., Smith G. C. (1982), Effects of chloride salts on physical, chemical and sensory properties of frankfurters, Journal of Food Science, 47 (6), pp. 1800-1802, DOI: 10.1111/j.1365-2621.1982.tb12886.x.

Hugas M., Garriga M., Monfort J. M. (2002), New mild technologies in meat processing: high pressure as a model technology, Meat Science, 62(3), pp. 359-371, DOI: 10.1016/S0309-1740(02)00122-5.

Inguglia E. S., Zhang Z., Tiwari B. K., Kerry J. P., Burgess C. M. (2017), Salt reduction strategies in processed meat products - A review, Trends in Food Science Technology, 59, pp. 70-78, DOI: 10.1016/j.tifs.2016.10.016.

Jayathilakan K., Sultana K., Pandey M. C. (2019), High-Pressure Processing of Meat, Fish, and Poultry Products, Non-thermal Processing of Foods, DOI: 10.1201/b22017.

Jimenez-Colmenero F., Fernandez P., Carballo J. L., Fernandez-Martin F. (1998), Highpressure-cooked Low-fat Pork and Chicken Batters as Affected by Salt Levels and Cooking Temperature, Journal of Food Science, 63(4), pp. 656-659, DOI: 10.1111/j.1365-2621.1998.tb15806.x.

Jung S., Ghoul M., Lamballerie-Anton M. D. (2003), Influence of high pressure on the color and microbial quality of beef meat, LWT-Food Science and Technology, 36(6), pp. 625-631, DOI: 10.1016/S0023-6438(03)00082-3.

Kang Z. L., Hu S. J., Zhu D. Y., Ma H. J. (2018), Effect of sodium chloride and processing methods on protein aggregation, physicalchemical and rheological properties of pork batters, International Journal of Food Engineer, 14, pp. 5-6, DOI: 10.1515/ijfe-2017-0319.

Kang Z. L., Li X., Ma H. J. (2017), Effect of the levels of transglutaminase in frankfurters: a physical-chemical and Raman spectroscopy study, CYTA - Journal of Food, 15(1), pp. 75-80, DOI: 10.1080/19476337.2016.1214928.

Kang Z. L., Zou Y. F., Xu X. L., Zhu C. Z., Wang P., Zhou G. H. (2014), Effect of a beating process, as a means of reducing salt content in Chinese-style meatballs (kung-wan): A physico-chemical and textural study, Meat Science, 96, pp. 147-152, DOI: 10.1016/j.meatsci.2013.09.024.

Kang Z., Li B., Ma H., Chen F. (2016), Effect of different processing methods and salt content on the physicochemical and rheological properties of meat batters, International Journal of Food Properties, 19(7), pp. 1604-1615, DOI: 10.1080/10942912.2015.1105819. 


\section{- Food Technology}

Khan M. A., Ali S., Abid M., Ahmad H., Zhang L., Tume R. K., Zhou G. (2014), Enhanced texture, yield and safety of a ready-to-eat salted duck meat product using a high pressure-heat process, Innovative Food Science and Emerging Technologies, 98, pp. $50-57$.

Ko W. C., Hsu K. C. (2002), Effect of high-pressure storage on the processing quality of tilapia meat, Progress in Biotechnology, 19(02), pp. 411-416, DOI: 10.1016/S09210423(02)80132-0.

Koutchma T. (2012), Design for High-Pressure Processing, in: Handbook of Food Process Design, J. Ahmed and M. Shafiur Rahman, Eds., ed Oxford: Wiley-Blackwell, pp. 998-1030.

Li Y. P., Kang Z. L., Sukmanov V., a, H. J. (2021), Effects of soy protein isolate on gel properties and water holding capacity of low-salt pork myofibrillar protein under high pressure processing, Meat Science, 176(2), 108471, DOI: 10.1016/j.meatsci.2021.108471.

Li Y. P., Kang Z. L., Sukmanov V., Ma H. J. (2021), Technological and functional properties of reduced-salt pork batter incorporated with soy protein isolate after pressure treatment, International Journal of Food Science Technology, Online, DOI: $10.1111 /$ ijfs. 15082 .

Li Y. P., Zhang X. H., Lu F., Kang Z. L. (2021), Effect of sodium bicarbonate and sodium chloride on aggregation and conformation of pork myofibrillar protein, Food Chemistry, 350(8), 129233, DOI: 10.1016/j.foodchem.2021.129233.

Li Y., Sukmanov V., Kang Z., Ma H. (2020), Effect of soy protein isolate on the technofunctional properties and protein conformation of low-sodium pork meat batters treated by high pressure, Journal of Food Process Engineering, 43(2), DOI: 10.1111/jfpe. 13343

Lu F., Kang Z. L., Wei L. P., Li Y. P. (2021), Effect of sodium bicarbonate on gel properties and protein conformation of phosphorus-free chicken meat batters, Arabian Journal of Chemistry, 14(2), 102969, DOI: 10.1016/j.arabjc.2020.102969.

Luisa A., Gaspar C., De Goes-Favoni S. P. (2015), Action of microbial transglutaminase (MTGase) in the modification of food proteins: A review, Food Chemistry, 2015, 171, pp. 315-322, DOI: 10.1016/j.foodchem.2014.09.019.

Ma H., Ledward D. A. (2013), High pressure processing of fresh meat - is it worth it?, Meat Science, 95(4), pp. 897-903, DOI: 10.1016/j.meatsci.2013.03.025.

Macfarlane J. J. (1985), High pressure technology and meat quality, Developments in Meat Science.

Maksimenko A., Kikuchi R., Tsutsuura S., Nishiumi T. (2020), Effect of high hydrostatic pressure in combination with low salt content for the improvement of texture and palatability of meat gels, IOP Conference Series: Earth and Environmental Science, 548(2), 022078. DOI: 10.1088/1755-1315/548/2/022078.

Mancini S., Nuvoloni R., Pedonese F., Paci G. (2019), Effects of garlic powder and salt additions in rabbit meat burgers: preliminary evaluation, Journal of Food Processing and Preservation, 43(3), e13877, DOI: 10.1111/jfpp.13894.

Mariutti L. R., Bragagnolo N. (2017), Influence of salt on lipid oxidation in meat and seafood products: a review, Food Research International, 94, pp. 90-100, DOI: 10.1016/j.foodres.2017.02.003.

Martínez-Onandi N, Sánchez C, Nuñez M, Picon. (2019), Microbiota of Iberian dry-cured ham as influenced by chemical composition, high pressure processing and prolonged refrigerated storage, A. Food Microbiol., 80, pp. 62-69, DOI: 10.1016/j.fm.2019.01.002. 
Ngarize S., Herman H., Adams A., Howell N. K. (2004), Comparison of changes in the secondary structure of unheated, heated and high-pressure treated .blactoglobulin and ovalbumin proteins using Fourier Transform Raman spectroscopy and self deconvolution, Journal of Agricultural and Food Chemistry, 52, pp. 6470-6477, DOI: $10.1021 / \mathrm{jf030649y.}$

Offer G., Trinick J. (1983), On the mechanism of water-holding in meat: the swelling and shrinking of myofibrils, Meat Science, 8, pp. 245-281, DOI: 10.1016/03091740(83)90013-X.

Oflynn C. C., Cruzromero M. C., Troy D. J., Mullen A. M., Kerry J. P. (2014), The application of high-pressure treatment in the reduction of salt levels in reducedphosphate breakfast sausages, Meat Science, 96(3), pp. 1266-1274, DOI: 10.1016/j.meatsci.2013.11.010.

Omana D. A., Plastow G., Betti M. (2011), Effect of different ingredients on color and oxidative characteristics of high pressure processed chicken breast meat with special emphasis on use of $\beta$-glucan as a partial salt replacer, Innovative Food Science and Emerging Technologies, 12, pp. 244-254, DOI: 10.1016/j.ifset.2011.04.007.

Orlien V. (2014), High pressure-induced changes in meat color, Reference Module in Food Science.

Park W. J., Jwa M. K., Hyun S. H., Lim S., Song D. J. (2006), Microbial and quality changes during storage of raw oyster treated with high hydrostatic pressure, Journal of the Korean Society of Food Science Nutrition, 35(10), pp. 1449-1455, DOI: 10.3746/jkfn.2006.35.

Pasin G., O’Mahony G., York B., Weitzel B., Gabriel L., Zeidler G. (1989), Replacement of sodiumchloride by modified potassium chloride (co-crystallised disodium-50inosinate and disodium-50-guan-ylate with potassium chloride) in fresh pork sausages, Journal of Food Science, 54(3), pp. 553-555. DOI: 10.1111/j.13652621.1989.tb04648.x.

Pateiro M., Munekata P. E. S., Cittadini A., Domínguez R., Lorenzo J. M. (2021), Metallicbased salt substitutes to reduce sodium content in meat products - science direct, Current Opinion in Food Science, 40, pp. 21-31, DOI: 10.1016/j.cofs.2020.10.029.

Paula M. M., Haddad G. D., Rodrigues L. M., Junior A. A., Ramos A. D., Ramos E. M. (2019), Effects of PSE meat and salt concentration on the technological and sensory characteristics of restructured cooked hams, Meat Science, 173, pp. 96-103, DOI: 10.1016/j.meatsci.2019.02.020.

Perrett S., Zhou J. M. (2002), Expanding the pressure technique: insights into protein folding from combined use of pressure and chemical denaturants, Biochim Biophys Acta, 1595(1-2), pp. 210-223, DOI: 10.1016/S0167-4838(01)00345-4.

Pretorius B., Schönfeldt H. C. (2018), The contribution of processed pork meat products to total salt intake in the diet, Food Chemistry, 238, pp. 139-145, DOI: 10.1016/j.foodchem.2016.11.078.

Rivas-Caedo A., Martínez-Onandi N., Gaya P., Nuez M., Picon A. (2021), Effect of highpressure processing and chemical composition on lipid oxidation, aminopeptidase activity and free amino acids of serrano dry-cured ham, Meat Science, 172, 108349, DOI: $10.1016 /$ j.meatsci.2020.108349.

Rospolski V., Koutchma T., Xue J., Defelice C., Balamurugan S. (2015), Effects of high hydrostatic pressure processing parameters and $\mathrm{NaCl}$ concentration on the physical properties, texture and quality of white chicken meat, Innovative Food Science and Emerging Technologies, 30, pp. 31-42, DOI: 10.1016/j.ifset.2015.04.003. 
Ruusunen M., Tirkkonen M.S., Puolanne E. (2001), Saltiness of coarsely ground cooked ham with reduced salt content, Agricultural and Food Science in Finland, 10, pp. 27-32, DOI: 10.23986/afsci.5676.

Sikes A. L., Tobin A. B., Tume R. K. (2009), Use of high pressure to reduce cook loss and improve texture of low-salt beef sausage batters, Innovative Food Science Emerging Technologies, 10, pp. 405-412.

Simonin H., Duranton F., Lamballerie M. D. (2012), New insights into the high-pressure processing of meat and meat products, Comprehensive Reviews in Food Science Food Safety, 11(3), pp. 285-306, DOI: 10.1111/j.1541-4337.2012.00184.x.

Sukmanov V., Ma H., Li Y. (2019a), Effect of high pressure and soy protein isolate combinations on the water holding capacity and texture of pork meat batters, Ukrainian Food Journal, 8(2), pp. 284-293.

Sukmanov V., Ma H., Li Y. (2019b), Effect of high pressure processing on meat and meat products. A review, Ukrainian Food Journal, 8(3), pp. 448-469.

Sun J., Wu Z., Xu X., Li P. (2012), Effect of peanut protein isolate on functional properties of chicken salt-soluble proteins from breast and thigh muscles during heat-induced gelation, Meat Science, 91(1), pp. 88-92, DOI: 10.1016/j.meatsci.2011.12.010.

Tauc P., Mateo C. R., Brochon J. C. (2002), Investigation of the effect of high hydrostatic pressure on proteins and lipidic membranes by dynamic fluorescence spectroscopy, Biochimica Et Biophysica Acta, 1595(1-2), pp. 103-115, DOI: 10.1016/S01674838(01)00338-7

Tintchev F., Bindrich U., Toepfl S., Strijowski U., Heinz V., Knorr D. (2013), High hydrostatic pressure/temperature modeling of frankfurter batters, Meat Science, 2013, 94(3), pp. 376-387, DOI: 10.1016/j.meatsci.2013.02.012.

Tobin B. D., O'Sullivan M. G., Hamill R. M., Kerry. J. P. (2013), The impact of salt and fat level variation on the physiochemical properties and sensory quality of pork breakfast sausages, Meat Science, 93, pp. 145-152, DOI: 10.1016/j.meatsci.2012.08.008.

Triki M., Khemakhem I., Trigui I., Ben Salah R., Jaballi S., Ruiz-Capillas C., Ayadi M. A., Attia H., Besbes S. (2017), Free-sodium salts mixture and AlgySalt ${ }^{\circledR}$ use as $\mathrm{NaCl}$ substitutes in fresh and cooked meat products intended for the hypertensive population, Meat Science, 133, pp. 194-203, DOI: 10.1016/j.meatsci.2017.07.005.

Tuboly E., Lebovics V. K., Gaal O., Meszaros L., Farkas J. (2003), Microbiological and lipid oxidation studies on mechanically deboned turkey meat treated by high hydrostatic pressure, Journal of Food Engineering, 56(2/3), pp. 241-244.

Wael M. Elamin, Johari B. Endan, Yus A. Yosuf, Rosnah Shamsudin and Anvarjon Ahmedov (2015), High Pressure Processing Technology and Equipment Evolution: A Review, Journal of Engineering Science and Technology Review 8(5), pp. 75-83, DOI: $10.25103 /$ jestr.085.11.

Wang L., Kong X., Jiang Y. (2021), Recovery of high pressure processing (HPP) induced injured Escherichia Coli 0157:H7 inhibited by lactobacillus sakei on vacuumpacked ground beef, Food Bioscience, 41, 100928, DOI: 10.1016/j.fbio.2021.100928.

Wang Y., Zhou Y., Wang X., Li P., Xu B., Chen C. (2020), Water holding capacity of sodium-reduced chicken breast myofibrillar protein gel as affected by combined $\mathrm{CaCl}_{2}$ and high-pressure processing, International Journal of Food Science Technology, 55(2), pp. 6010-609. DOI: 10.1111/ijfs.14313. 


\section{- Food Technology ——}

Warner R. D., Ha M. (2019), Utilising High Pressure Processing for Meat Tenderisation. In book: Reference Module in Food Science, pp. 1-6, DOI: 10.1016/B978-0-08100596-5.21348-6.

Wei L. P., Li Y. P., Wang C. Y., Kang Z. L., Ma H. J. (2019), Thermal gel properties and protein conformation of pork batters as affected by high pressure and temperature. International, Journal of Food Properties, 22(1), pp. 1492-1500, DOI: 10.1080/10942912.2019.1657444

World Health Organisation. (2007), Reducing salt intake in populations. Report of a WHO Forum and Technical Meeting.

Xu H., Zhang X. K., Wang X., Liu D. (2019), The effects of high pressure on the myofibrillar structure and meat quality of marinating tan mutton, Journal of Food Process Engineering, 42(4), DOI: 10.1002/jsfa.1613.

Xu Y., Liu L. (2016), Structural and Functional Properties of Soy Protein Isolates Modified by Soy Soluble Polysaccharides, Journal of Agricultural and Food Chemistry, 64(38), pp. 7275-7284, DOI: 10.1021/acs.jafc.6b02737.

Yang H., Han M., Wang X., Han Y., Wu J., Xu X., Zhou G. (2015), Effect of high pressure on cooking losses and functional properties of reduced-fat and reduced-salt pork sausage emulsions, Innovative Food Science and Emerging Technologies, 29, pp. 125-133.

Yang H., Tao F., Cao G., Han M., Shen Q. (2021), Stability improvement of reduced-fat reduced-salt meat batter through modulation of secondary and tertiary protein structures by means of high pressure processing, Meat Science, 108439, DOI: 10.1016/j.meatsci.2021.108439.

Yao J., Zhou Y., Chen X., Ma F., Li P., Chen C. (2017), Effect of sodium alginate with three molecular weight forms on the water holding capacity of chicken breast myosin gel, Food Chemistry, 239, pp. 1134-1142, DOI: 10.1016/j.foodchem.2017.07.027.

Yuste J., Mor-Mur M., Capellas M. (1999), Listeria innocua and aerobic mesophiles during chill storage of inoculated mechanically recovered poultry meat treated with high hydrostatic pressure, Meat Science, 53(4), p. 251, DOI: 10.1016/S03091740(99)00064-9.

Zhang W., Naveena B. M., Jo C., Sakata R., Zhou G., Banerjee R., Nishiumi T. (2017), Technological demands of meat processing-An Asian perspective, Meat Science, 132, pp. 35-44, DOI: 10.1016/j.meatsci.2017.05.008.

Zhang Y., Wu J., Jamali M. A., Guo X., Peng Z. (2017), Heat-induced gel properties of porcine myosin in a sodium chloride solution containing L-lysine and L-histidine, LWT - Food Science and Technology, 85, pp. 16-21, DOI: 10.1007/s10068-0170081-7.

Zhang Z., Yang Y., Zhou P., Zhang X., Wang J. (2017), Effects of high pressure modification on conformation and gelation properties of myofibrillar protein, Food Chemistry, 217, pp. 678-686, DOI: 10.1016/j.foodchem.2016.09.040.

Zheng H., Han M., Bai Y., Xu X., Zhou G. (2019), Combination of high pressure and heat on the gelation of chicken myofibrillar proteins, Innovative Food Science and Emerging Technologies, 52, pp. 122-130.

Zheng H., Han M., Yang H., Tang C., Xu X., Zhou G. (2017), Application of high pressure to chicken meat batters during heating modifies physicochemical properties, enabling salt reduction for high-quality products, LWT - Food Science and Technology, 84, pp. 693-700, DOI: 10.1016/j.lwt.2017.06.006. 
Zheng H., Han M., Yang H., Tang C., Xu X., Zhou G. (2017), Application of high pressure to chicken meat batters during heating modifies physicochemical properties, enabling salt reduction for high-quality products, LWT - Food Science and Technology, 84, pp. 693-700, DOI: 10.1016/j.lwt.2017.06.006.

Zheng H., Xiong G., Han M., Deng S., Xu X., Zhou G. (2015), High pressure/thermal combinations on texture and water holding capacity of chicken batters, Innovative Food Science Emerging Technologies, 30, pp. 8-14.

Zhu D. Y., Kang Z. L., Ma H. J., Xu X. L., Zhou G .H. (2018), Effect of sodium chloride or sodium bicarbonate in the chicken batters: A physico-chemical and Raman spectroscopy study, Food Hydrocolloids, 83, pp. 222-228, DOI: 10.1016/j.foodhyd.2018.05.014. 